\title{
O TEMPO DA JUSTIÇA DE TRANSIÇÃO NO BRASIL
}

\section{THE TIME OF TRANSITIONAL JUSTICE IN BRAZIL}

\author{
Marcelo Pires Torreão \\ Universidade de Brasília (UnB) - Brasil \\ Eneá de Stutz e Almeida \\ Universidade de Brasília (UnB) - Brasil
}

SUMARIO: I - INTRODUÇÃO. II - CONCEPÇÕES SOBRE O TEMPO. III O TEMPO EM FRANÇOIS OST. IV - OS TEMPOS SOCIAIS NO PROCESSO TRANSICIONAL BRASILEIRO. V - O TEMPO SOCIAL DA JUSTIÇA DE TRANSIÇÃO NO BRASIL. VI- CONSIDERAÇÕES FINAIS. BIBLIOGRAFIA.

Resumen: Este artigo resgata alguns conceitos doutrinários sobre o tempo até sua compreensão como uma instituição social, com referencial teórico no filósofo belga François Ost. Com base nessa concepção, o trabalho examina características de quatro momentos no período transcorrido entre o golpe civil-militar e a democracia constitucional no Brasil. Conclui-se que o processo transicional brasileiro se revela atrasado e inacabado. No momento em que a Constituição brasileira completa mais de trinta anos, é urgente retomar o processo constitucional de transição, sob pena de surgirem fissuras no Estado Democrático de Direito brasileiro.

\begin{abstract}
This paper redeems scholarly understandings of time until the emergence of time as a social institution, as referred by François Ost. Based on this conception, the characteristics of four main moments, during the period stemming from the civil-military coup and the constitutional democracy in Brazil, are approached. In conclusion, transitional process in Brazil is a late and unfinished process. At the time that the Federal Constitution is completing more than thirty years old, is urgent to get back to constitutional transitional process, in order to avoid problems in Democratic Rule of Law in Brazil.
\end{abstract}

Palabras clave: Justiça de Transição; Tempo Social; Ditadura; Democracia; Constituição.

Key Words: Transitional Justice; Social Time; Dictatorship; Democracy; Constitution. 


\section{INTRODUÇÃO}

O problema investigado nesta pesquisa consiste em analisar em que tempo social se insere a Justiça de Transição no Brasil. Para essa finalidade, serão examinadas diferentes concepções sobre o tempo até sua compreensão como instituição social. A partir desse entendimento, o artigo objetiva analisar as temporalidades sociais relativas ao processo transicional brasileiro, desde o golpe civil-militar de 1964 até a redemocratização constitucional, na qual se insere a agenda de implantação da Justiça de Transição.

Justifica-se esta pesquisa em razão das posturas atuais de autoridades brasileiras que insistem em negar o passado ditatorial e exaltar regimes de exceção. O presente estudo é interdisciplinar e traz aproximações entre os campos da História, da Filosofia e do Direito. A metodologia utilizada na pesquisa é bibliográfica e documental. Foram utilizados textos de doutrina, bases legislativas, documentos históricos, acórdãos judiciais e relatórios de pesquisas de opinião.

O trabalho se inicia com a apresentação de diferentes estudos sobre o tempo (II). Nesse tópico, são apresentadas diferentes interpretações, que evoluíram até alcançar a compreensão do tempo como uma instituição social. Em seguida, o trabalho investiga a compreensão do tempo em François Ost (III). Nesse ponto, desenvolvemse as características jurídicas do tempo em sociedade, com base nos conceitos de memória, perdão, promessa e requestionamento. Com essa base teórica, são investigadas as quatro temporalidades da última experiência ditatorial brasileira (IV). São explorados o tempo do golpe civil-militar de 1964, o tempo do governo ditatorial, o tempo da Constituinte e o tempo da democracia constitucional ${ }^{1}$. Na temporalidade da democracia, a investigação concentra-se no tempo da Justiça de Transição no Brasil (V). Por fim, são apresentadas as considerações finais sobre o trabalho e as referências bibliográficas.

\section{CONCEPÇÕES SOBRE O TEMPO}

O tempo tem sido objeto de instigação em variados campos do conhecimento humano. Filósofos, psicólogos, biólogos, matemáticos, físicos, religiosos, sociólogos e juristas desenvolveram diferentes interpretações sobre o tempo e suas implicações na vida em sociedade. Neste tópico, realiza-se uma sucinta exposição de algumas dessas concepções.

Os primeiros estudos registrados identificavam o tempo com o movimento dos astros celestes. Essa foi a concepção trazida por Platão, sob influência de Pitágoras. No diálogo Timeu, Platão registrou a

1 Agradecemos ao Professor Cristiano Paixão, da Universidade de Brasília (UnB), pelo plano de ensino e debates que influenciaram a redação do tópico IV deste artigo. Eventuais críticas são, todavia, de responsabilidade dos Autores. 
divisibilidade do tempo, medida pelos círculos completos dos astros ${ }^{2}$. Sob outro enfoque, Aristóteles relacionou o tempo com as ideias de passado e futuro, sucessões de acontecimentos e também com o padecimento dos seres ${ }^{3}$. Para Aristóteles, o tempo não era o próprio movimento, mas sim uma noção abstrata e autônoma, que se revelava na fluidez entre passado o futuro ${ }^{4}$. Em sentido semelhante, Plotino definiu o tempo como um movimento da alma. Segundo esse filósofo, sem o tempo não há existência. Quando a alma passa a se movimentar em direção ao futuro, inicia-se a contagem do tempo e a existência propriamente dita 5 .

A ideia de diferentes movimentos temporais foi trabalhada por Agostinho. No décimo primeiro capítulo das Confissões, Agostinho relata que o tempo não é representado pelos movimentos do sol, da lua e das estrelas, mas sim pelos movimentos de todos os $\operatorname{corpos}^{6}$. Essa premissa considerava o tempo como um elemento único, mas com diferentes experiências observadas no transcurso dos momentos.

No capítulo da Estética Transcendental da Crítica da Razão Pura, Kant sustenta que o tempo não deriva da experiência. O tempo é antecedente à experiência e consiste na própria condição de possibilidade de qualquer fenômeno. A partir dessa premissa, Kant observa a existência de fenômenos cronológicos em tempos iguais, chamados de simultâneos, e em tempos diferentes, denominados sucessivos ${ }^{7}$.

A percepção do tempo pelo indivíduo avançou nos estudos de Bergson. Esse autor diferenciou o tempo dos cientistas, denominado fictício, do tempo captado pelo individuo, chamado de tempo $\mathrm{real}^{8}$. O tempo fictício representaria um simples vazio no qual sucedem os acontecimentos, enquanto o tempo real compreende os próprios acontecimentos físicos e psicológicos na visão de quem os experimenta. Esse tempo real seria formado por sucessão, continuidade, mudança,

2 Platão, Timeu-Critias, Trad. Rodolfo Lopes, Centro de Estudos Clássicos e Humanísticos, Coimbra, 2011, pp. 113.

3 Aristóteles, Fisica I e II, Trad. Lucas Angioni, Unicamp, Campinas, 2009, pp. 340.

4 José Reis, "Estudo sobre o Tempo", Revista Filosófica de Coimbra Vol. 5 n ${ }^{\circ}$, Instituto de Estudos Filosóficos da Faculdade de Letras da Universidade de Coimbra, Coimbra, 1996, pp. 146.

5 José Reis, Estudo sobre o Tempo, op. cit., pp. 397.

6 Agostinho, Confissões, Livro XI, Trad. Arnaldo do Espírito Santo et al, Luso Sofia Press, Covilhã, 2008, pp. 119.

7 Emmanuel Kant, Crítica da Razão Pura, Trad. J. Rodrigues de Merege, Acrópolis, São Paulo, 2001, pp. 37.

8 Henri Bergson, Obras Escogidas, Trad. José Antonio Miguez, Aguilar S.A. de Ediciones, Cidade do México, 1963, pp. 138. 
memória e criação. Em caminho semelhante, Brentano desenvolveu o conceito de temporalidade como decorrência da imaginação do sujeito ${ }^{9}$.

Com base no método fenomenológico, Husserl afastava as concepções indutivas ou dedutivas sobre as temporalidades. Em Lições sobre o Tempo, o passado e o futuro foram tratados como objetos não apenas imaginados, mas efetivamente percebidos pela experiência do individuo. Dessa forma, apenas algumas propriedades do tempo poderiam ser capturadas como parte subjetiva da consciência individual $^{10}$. Na obra Ser e Tempo, Heidegger não trata o tempo como um ente, mas como um existencial, um fundamento ontológico para a existência do Dasein. Nessa concepção, o tempo é visto como o nome do ser e só a partir da temporalidade é possível entender a constituição originária do Dasein ${ }^{11}$.

Em linhas gerais, os pensamentos expostos acima podem ser classificados em dois grandes grupos: aqueles que tratam do tempo como um fenômeno físico e outros que o consideram uma experiência subjetiva $^{12}$. No campo do conhecimento humanista, uma outra percepção foi desenvolvida para compreender o tempo como uma construção da sociedade, como ocorre, por exemplo, nos usos de diferentes calendários em distintas culturas ${ }^{13}$. Tal noção representa $o$ tempo como um ente público, uma criação da coletividade, um organismo social. Esse conceito do tempo social progrediu em diferentes extensões do pensamento contemporâneo, na história, na sociologia, na politica, na cultura e no direito.

No campo histórico-geográfico, Fernand Braudel desenvolve o conceito de tempo de longa duração, associado à ideia de estruturas que permanecem estáveis no decorrer da história. Por exemplo, o chamado período da revolução industrial, situado entre a metade do século dezoito e as primeiras décadas do século dezenove; o período da teoria gravitacional newtoniana, que se estendeu por três séculos até a elaboração da teoria da relatividade; ou o momento situado entre os anos de 1964 e 1988, denominado de período da ditadura brasileira ${ }^{14}$.

9 Franz Brentano, Psychology from an Empirical Standpoint, Trad. Rancurello, A.C. et al., Routledge, Londres, 1995, pp. 23.

10 Edmund Husserl, Leçons pour une phénoménologie de la conscience intime du temps, Trad. Henri Dussort, Presses Universitaires de France, Paris, 1964, pp. 59.

${ }^{11}$ Martin Heidegger, Ser e tempo, Trad. Fausto Castilho, Unicamp, Campinas, 2012, pp. 649.

12 Algumas percepções identificam o tempo como uma combinação entre o fenômeno científico e a percepção individual.

${ }_{13}$ Cristiano Paixão, Modernidade, tempo e direito, Del Rey, Belo Horizonte, 2002, pp. 119-128.

14 Fernand Braudel, La historia y las ciencias sociales, Trad. Josefina Gómes Mendonza, $3^{\mathrm{a}}$ ed., Alianza Editorial, Madrid, 1974, pp. 68. Cristiano Paixão, Modernidade, tempo e direito, op. cit., pp. 139. Henry Rousso, A última catástrofe: a história, o presente, o contemporâneo, Trad. Fernando Coelho e Francisco Coelho, FGV, Rio de Janeiro, 2016, pp. 269. 
Na obra Futuro Passado, Koselleck aprimorou a concepção do tempo histórico por meio de duas categorias inter-relacionadas: o espaço de experiência e o horizonte de expectativa ${ }^{15}$. Em Tempo e Narrativa, o filósofo francês Paul Ricœur realiza a distinção entre tempo histórico, tempo cósmico e tempo individual ${ }^{16}$.

$\mathrm{Na}$ sociologia, Luhmann conceitua o tempo como uma interpretação social sobre as ideias de passado e futuro ${ }^{17}$. Na obra Encruzilhadas do Labirinto, Castoriadis desenvolve a ideia do tempo como uma identidade social ${ }^{18}$. No livro Entre o Passado e o Futuro, Hannah Arendt justifica a crise politico-cultural da sociedade em razão da inaptidão coletiva em articular esses dois tempos ${ }^{19}$.

No plano jurídico, o tempo como instituição social é uma das premissas adotadas por François Ost para o desenvolvimento da obra $O$ Tempo do Direito ${ }^{20}$. Nesse livro, o autor analisa o tempo sob uma perspectiva jurídica e compreende o direito como um instrumento para a construção de um tempo plural e coletivo. Esse filósofo investiga a dialética entre o tempo e o direito, duas instituições sociais que se relacionam em mútua e constante interferência ${ }^{21}$. Situada nesse pensamento, a obra de Ost explora as relações entre a temperança e a justiça, ou seja, entre a sabedoria do tempo e a sabedoria do direito. Vale expor algumas ideias sobre as temporalidades do direito trazidas por esse filósofo, que interessam ao presente trabalho.

15 Reinhart Koselleck, Futuro pasado: para una semántica de los tiempos históricos, Trad. Norberto Smilg, Paidós, Barcelona, 1993, pp. 337. Cristiano Paixão. Modernidade, tempo e direito, op. cit., pp. 143.

16 Paul Ricœur, Tempo e Narrativa, Tomo III, Trad. Roberto Leal Ferreira, Papirus, Campinas, 1997, pp. 180.

17 Niklas Luhmann, The differentiation of society, Trad. Stephen Holmes e Charles Larmore, Columbia University Press, Nova Iorque, 1982, pp. 274.

18 Cornelius Castoriadis, As encruzilhadas do labirinto III: o mundo fragmentado, Trad. Rosa Maria Boaventura, Paz e Terra, Rio de Janeiro, 1992, pp. 279.

19 Hannah Arendt, Entre o passado e o futuro, Trad. Mauro W. Barbosa, Perspectiva, São Paulo, 2016, pp. 248.

20 François Ost, O tempo do direito, Trad. Maria Fernanda Oliveira, Instituto Piaget, Lisboa, 1999, pp. 12. Para outros trabalhos que tratam do tempo como um fenômeno social, ver: Norbert Elias, Du Temps, Trad. M. Hulin, Fayard, Paris, 1996, pp. 52. Cornelius Castoriadis, A instituição imaginária da sociedade, $3^{\mathrm{a}}$ ed., Paz e Terra, Rio de Janeiro, 1982, pp. 243. Marcelo Jasmin, “Futuro(s) presente(s)", Em: Adauto Novaes (Org.), Mutações: o futuro não é mais o que era, Edições SESC, São Paulo, 2013, pp. 388. Manoel Luíz Salgado Guimarães, "O presente do passado: as artes de Clio em tempos de memória". Em: Martha de Abreu; Rachel Soihet; Rebeca Gontijo (Org.), Cultura Politica e leituras do passado: historiografia e ensino de história, Civilização Brasileira, Rio de Janeiro, 2007, pp. 36. Flávia Biroli, "Representações do golpe de 1964 e da ditadura na midia: sentidos e silenciamentos na atribuição de papéis à imprensa", 1984-2004, Varia Historia, Vol. 25, n 41, jan/jun 2009, pp. 271.

${ }^{21}$ Nas palavras do autor: "O direito afecta directamente a temporalização do tempo, ao passo que, em compensação, o tempo determina a força instituinte do direito", ou seja, "o direito temporaliza ao passo que o tempo institui". François Ost, O tempo do direito, op. cit., pp. 14. 


\section{O TEMPO EM FRANÇOIS OST}

As interações entre o tempo e o direito são tratadas por François Ost como um compasso, em analogia à organização da linguagem musical $^{22}$. O filósofo belga trabalha o livro em quatro temporalidades: no lado do passado, há o tempo da memória e o tempo do perdão; no lado do futuro, encontra-se o tempo da promessa e o tempo do requestionamento ${ }^{23}$. Essas quatro categorias, tão jurídicas quanto temporais, apresentam-se interdependentes, conectadas e dialéticas. Isoladas, qualquer dessas quatro dimensões seria capaz de produzir destemporalização e violência ${ }^{24}$.

O primeiro tempo instituidor de Ost é o da memória, um ato de ligar o passado 25 . A memória recorda, certifica e institui a consciência coletiva. Uma sociedade sem memória permanece imobilizada, eternamente em busca de sua própria identidade. Cabe ao jurista a tarefa de servir como guardião dessa memória social. Ao tratar da memória no momento de uma ordem jurídica constituinte, Ost afasta a ideia apresentada por Derrida de que a lei surge como uma ruptura violenta com a ordem anterior e alinha-se ao fundamento trazido por Ricœur de que toda lei guarda fundamento em seu passado:

"É todavia possivel interpretar de outra forma a retirada do fundamento e ler nela, não um vazio e um desmame [como observado por Derrida], mas pelo contrário um elo que não para de se estender e de se enriquecer em direção a um passado que nunca deixou de irradiar em direção ao presente. Esta segunda leitura é a de Paul Ricœur que, depois de ter observado, como vimos, que 'a origem da autoridade é fugidia', não deduz disso que cabe ao contemporâneo - nem sequer ao juiz constitucional, tão louvado, nem às regras da discussão processual sobre as condições da legitimidade, de que tanto esperamos hoje 'produzir simbólico (fundador) a partir do vazio'. Para dizer a verdade, tal pretensão não se afastaria muito dos fantasmas de todos os totalitarismos que sempre pretenderam partir do zero para criar um tipo de homem absolutamente novo"26.

A segunda figura temporal de Ost consiste no perdão, ou seja, desligar $\mathrm{o}$ passado ${ }^{27}$. $\mathrm{O}$ ato de perdoar, entretanto, não significa esquecer. $\mathrm{Na}$ verdade, o perdão objetiva substituir o caminho da vingança, que seria trilhado pela exacerbação da memória, por uma

22 François Ost, O tempo do direito, op. cit., pp. 18.

23 No livro O Tempo do Direito, cada um dos quatro tempos é tratado em um capítulo próprio. Além desses quatro capítulos, a obra denomina o capítulo inicial de prelúdio, em referência às peças musicais introdutórias, e o capítulo final é chamado de interlúdio, em referência ao intervalo entre duas partes de uma mesma composição.

\footnotetext{
${ }^{24}$ François Ost, O tempo do direito, op. cit., pp. 19.

${ }^{25}$ François Ost, O tempo do direito, op. cit., pp. 52.

${ }^{26}$ François Ost, O tempo do direito, op. cit., pp. 74 e 75.

${ }^{27}$ François Ost, O tempo do direito, op. cit., pp. 139.
} 
passagem que permite a aplicação da justiça e uma consequente abertura para um novo pacto. O filósofo ilustra o perdão por meio de uma passagem da tragédia grega Euménides, quando o julgamento de Orestes põe termo ao ciclo de revanchismo familiar. Assim, o perdão se apresenta como liame entre a recordação passada e o compromisso futuro:

"A vingança é finalmente substituída pela justiça, a deliberação toma a dianteira da violência, ao passo que o tempo da memória dá lugar ao do perdão [...] a natureza dialética do perdão surge assim à plena luz, já que a montante, remete para a memória (a falta não é esquecida, mas reconhecida e assumida) e a jusante, desemboca na promessa (a aposta confiante num outro cenário de futuro)"28.

O terceiro tempo de Ost é o da promessa, uma ação de ligar o futuro $^{29}$. O compromisso reduz a imprevisibilidade das incertezas do amanhã e norteia os rumos das relações para uma direção oposta aos erros identificados no passado. Por meio da promessa, as normas jurídicas legitimam-se pela confiança que nelas a sociedade deposita. Constituições, leis e contratos contribuem para prever situações jurídicas e alcançar um desejável fluxo de ordem nas relações sociais. Todavia, as normas aprisionam o futuro e são capazes de propiciar situações de perpetuação no poder, concentração econômica e assimetrias sociais, que não encontram limites no tempo, a exemplo de compromissos perpétuos e rendas vitalícias, justificadas pelo afinco desmedido às promessas:

"Esta fuga para frente, este apego crispado a um futuro intangivel, esse futuro simples que gostariamos de libertar dos sedimentos do passado, subtrair às rupturas do presente e preservar dos requestionamentos ulteriores, é finalmente um futuro sem futuro, um tempo estéril e sem amanhã. [...] Visa-se antes a louca pretensão apresentada por vezes por constituintes, legisladores e simples particulares de subtrair absolutamente à acção do tempo a norma que adoptam inscrevendo-a num futuro intangivel. Fantasmas de eternidade; desejos explícitos de perenizar a sua vontade; 'sofismas daqueles que pretendem agrilhoar a posteridade', dizia Bentham"30.

Por isso, a quarta temporalidade é o requestionamento, ato de desligar o futuro ${ }^{31}$. Pela via do requestionamento, o amanhã é libertado, desobrigado. O liame entre memória e promessa passa a ser compreendido como uma possibilidade, não como uma obrigação. Compreender o direito de forma fluida, flexibilizar normas e renovar debates sobre o que fora instituído são aberturas que dão lugar a um pluralismo de verdades, aceitações de mudanças. $\mathrm{O}$ ato de revisar

\footnotetext{
28 François Ost, O tempo do direito, op. cit., pp. 148 e 175.

29 François Ost, O tempo do direito, op. cit., pp. 197.

30 François Ost, O tempo do direito, op. cit., pp. 315.

31 François Ost, O tempo do direito, op. cit., pp. 325.
} 
representa a oportunidade de corrigir erros em um constante processo de construções e desconstruções jurídicas:

"Garantir a abertura do futuro seria a tarefa prioritária tanto da ciência (libertada dos dogmas), como do mercado (libertado dos limites institucionais), e da democracia (privada das grandes narrativas, finalmente adulta). [...] No final do percurso, o cepticismo poderia paralisar o trabalho do conhecimento, tal como o recuso sobre o privado poderia minar o compromisso político. Mas o requestionamento não desemboca necessariamente neste cenário destruidor. Podemos também concebê-lo como uma radicalização da modernidade que permanece, como escrevia Habermas, um 'projeto inacabado" 32.

Mesmo o tempo do requestionamento, se conduzido ao extremo, pode se revelar autodestruidor em razão do seu coeficiente de incertezas ${ }^{33}$. Assim, a tese central da obra O Tempo do Direito reside na compreensão de que qualquer temporalidade absoluta é potencialmente trágica. Qualquer dos quatro elementos temporais, quando destemperados, é capaz de gerar a ilegalidade por meio do direito ${ }^{34}$.

Portanto, a medida de incidência do direito é um componente fundamental para que as normas sejam adequadas ao seu tempo. $\mathrm{O}$ jurista carrega a responsabilidade de ponderar simultaneamente essas quatro temporalidades ao equacionar a aplicação do direito. Essa tarefa opera-se sempre no presente e permite a realização da justiça por meio da melhor expressão do direito em coerência com o seu tempo social ${ }^{35}$.

Duas principais ideias no referencial teórico de François Ost contribuem para o presente estudo. Em primeiro lugar, a compreensão do tempo como uma instituição social e jurídica. Esse ponto de vista permite observar fragmentos temporais de determinadas sociedades sob seus aspectos jurídicos e constitucionais. Em segundo, o entendimento de que a relação entre o tempo e o direito deve conjugar memória, perdão, promessa e requestionamento. Esses quatro conceitos devem ser constantemente medidos e reequilibrados. O descomedimento ou a insuficiência de qualquer desses elementos propicia o surgimento de desequilibrios, conflitos e injustiças sociais.

Tais bases conduzem este trabalho a observar as características dos tempos sociais que se relacionam com a experiência brasileira da última ditadura, desde o golpe civil-militar até o retorno ao constitucionalismo democrático e posterior fase de implantação da Justiça de Transição. A partir dessa observação, podem ser analisadas exacerbações ou faltas dos elementos de memória, perdão, promessa e requestionamento em cada tempo social. Essa é a análise que se segue no tópico abaixo.

\footnotetext{
32 François Ost, O tempo do direito, op. cit., pp. 326 e 327.

33 François Ost, O tempo do direito, op. cit., pp. 429.

34 François Ost, O tempo do direito, op. cit., pp. 325.

35 François Ost, O tempo do direito, op. cit., pp. 425, 429 e 435.
} 


\section{OS TEMPOS SOCIAIS NO PROCESSO TRANSICIONAL BRASILEIRO}

O tempo é um importante ator no processo transicional, pois traduz indicativos de rupturas, permanências, durações, urgências e atrasos nos ciclos históricos. Com base na concepção de tempo social, é possivel identificar padrões característicos nos períodos transcorridos desde a instauração da ditadura até a redemocratização constitucional. Para os fins buscados nesta etapa, identificam-se quatro tempos sociais que se relacionam diretamente com a transição brasileira: a) o tempo do golpe; b) o tempo da ditadura; c) o tempo da constituinte; e d) o período pós-constituição, no qual se encontra inserido o tempo da Justiça de Transição. Cumpre analisar os traços de identificação desses quatro períodos.

A primeira temporalidade social, referente ao golpe civil-militar, é marcada por duas principais características: antecedência e urgência. As marcas da ditadura militar, como autoritarismo, repressão, nacionalismo e censura, não se distanciavam de um perfil já observado anteriormente na história brasileira, por exemplo, no Estado Novo (1937-1945) ${ }^{36}$. As experiências precedentes e as permanências autoritárias possibilitaram adotar medidas rápidas no momento da efetivação do golpe, conforme aponta a Professora Lucília Delgado:

"A história é um processo marcado por rupturas e continuidades. O ano de 1964 nasceu marcado pela continuidade de profundas desavenças politicas que alimentavam a história brasileira desde 1930 . Divergências que se tornaram mais complexas a partir do início da década de 1964, mas que reeditavam velhas tramas e conflitos"37.

No período de relativa democracia (1946-1964), o pensamento arbitrário e o imaginário anticomunista seguiram presentes nas forças armadas $^{38}$. No ano de 1961, após a renúncia de Jânio Quadros, os Ministros Militares da Guerra, Marinha e Aeronáutica lançaram um manifesto, por meio do qual se posicionavam expressamente contrários ao retorno de João Goulart ao Brasil para posse como Presidente da

36 O Estado Novo foi o regime político brasileiro, instaurado por meio de golpe de Estado e que vigorou de 10/11/1937 a 31/01/1946 sob o comando de Getúlio Vargas. A exemplo do que viria a ocorrer na ditadura de 1964, a Era Vargas também foi marcada por censura, centralização poder, autoritarismo, nacionalismo e um ideal anticomunista.

37 Lucilia Neves Delgado, "Brasil: 1954 - Prenúncios de 1964". Varia Historia, Vol. $21, \mathrm{n}^{\circ} 34$, jul. 2005, pp. 502. Na mesma linha: "Refizeram a velha rota que levou à traição da república em 1889, à traição da Aliança Liberal, em 1930, à traição da Constituição de 1946 e à traição de uma experiência promissora de democracia de participação ampliada nos começos da década de 1960". Florestan Fernandes. A Constituição inacabada - vias históricas e significado politico. Estação Liberdade, São Paulo, 1989, pp. 51.

38 Maud Chirio, A politica nos quartéis: revoltas e protestos de oficiais na ditadura militar brasileira, Trad. André Telles, Zahar, Rio de Janeiro, 2012, pp. 18. 
República ${ }^{39}$. Esse manifesto trazia argumentações de ilegalidade e expressava o absoluto apoio do Presidente da República interino, deputado Ranieri Mazzilli40. O manifesto foi apresentado apenas cinco dias após a renúncia de Jânio Quadros (30/08/1961), mas alguns anos antes do golpe que se completaria posteriormente (31/03/1964). O arranjo político entregou a João Goulart a Presidência da República em um sistema parlamentarista, com menos poderes do que o sistema presidencialista que então vigorava ${ }^{41}$. Portanto, de certa forma, o manifesto dos militares pode ser considerado parcialmente vitorioso ${ }^{42}$.

A marcha das tropas lideradas pelo general Olympio Mourão Filho, que exigiram a renúncia do Presidente João Goulart, ocorreu na madrugada de uma terça-feira (31/03/1964). Foram necessários sete dias (07/04/1964) para que o jurista Francisco Campos, um dos autores intelectuais da Constituição de 1937, apresentasse ao Ministro da Guerra, Costa e Silva, bem como ao General Castello Branco, as justificativas estratégicas para a mudança da ordem constitucional por meio da ideia de uma revolução ${ }^{43}$. Dois dias após essa reunião

39 Jânio Quadros exerceu o cargo de Presidente do Brasil entre 31 de janeiro de 1961 e 25 de agosto de 1961, data em que apresentou carta de renúncia. Jânio Quadros esperava continuar no poder, caso o nome de seu Vice-Presidente, João Goulart, não fosse aceito pelo Congresso Nacional. João Goulart tinha ligações com sindicalismo e com posições consideradas de esquerda. Contudo, o nome de João Goulart foi aceito pelo Congresso Nacional para assumir a Presidência no Brasil. Como João Goulart encontrava-se em visita à China, o Presidente da Câmara dos Deputados, Ranieri Mazzilli assumiu, em caráter interino, a Presidência da República. $\mathrm{Na}$ ocasião, o Presidente interino Ranieri Mazzilli leu ao Congresso Nacional um comunicado dos ministros militares das três Foças Armadas, que ameaçava Goulart de prisão, caso retornasse ao Brasil. João Goulart regressou ao país, mas ainda havia grande resistência, especialmente de setores militares e de alguns politicos, que tentaram impedir sua posse na Presidência. Sucedeu-se, então, a Campanha da Legalidade, uma mobilização que tinha objetivo de garantir a manutenção da ordem jurídica com a consequente posse prevista de João Goulart, o que veio ocorrer em 7 de setembro de 1961.

40 Auro Moura Andrade, Um Congresso contra o arbitrio: diários e memórias, Nova Fronteira, Rio de Janeiro, 1985, pp. 396.

${ }^{41}$ Para sanar o impasse criado com a renúncia de Jânio Quadros e garantir a posse de João Goulart, o Congresso Nacional utilizou de emenda constitucional para instituir o parlamentarismo. $O$ parlamentarismo reduziu as prerrogativas do Presidente da República e essa solução foi aceita por João Goulart, a fim de viabilizar sua posse na Presidência. Posteriormente, João Goulart se articulou politicamente e submeteu essa questão a um plebiscito, que restabeleceu o sistema presidencialista no país, em janeiro de 1963.

42 Esse é o argumento defendido por: Daniel de Mendonça, "O golpe civil-militar de 1961: Crítica a uma explicação hegemônica", Em: Política e Sociedade, $\mathrm{n}^{\circ} 14$, abril de 2009 , pp. 443. Com ponto de vista similar: "Seria possivel dizer que o golpe que levou os militares brasileiros ao poder ocorreu não uma, mas duas vezes - primeiro em 1961, quando o alto-comando militar se colocou, sem sucesso, contra a posse de João Goulart na presidência e, de novo em 1964". Anthony W. Pereira, Ditadura e repressão: o autoritarismo e o estado de direito no Brasil, no Chile e na Argentina, Trad. Patricia de Queiroz Carvalho Zimbres, Terra e Paz, São Paulo, 2010, pp. 88.

${ }^{43}$ Marcelo Cattoni de Oliveira; Rafael Dilly Patrus, "Constituição e poder constituinte no Brasil pós-1964: o processo de constitucionalização brasileiro entre 'transição $e$ 
(09/04/1964), foi editado o primeiro ato institucional do governo militar. No preâmbulo do Ato Institucional $\mathrm{n}^{\circ} 1$, registrava-se que, a partir daquele momento, a revolução estaria investida no exercício do Poder Constituinte para "tomar medidas urgentes"44. Após mais dois dias (11/04/1964), Castelo Branco seria escolhido para a Presidência da República.

Em menos de duas semanas, não apenas o governo havia sido deposto, mas também haviam sido derrubadas as bases normativas da Constituição de 1946. Embora mantida, a carta constitucional passou a ser submetida à então nominada revolução ${ }^{45}$. A urgência no rearranjo institucional acompanhava-se de uma aparência de legalidade e democracia, conforme observa Carlos Fico: “a temporalidade dos generais tanto guardava relação com a suposta urgência de saneamento do país - por meio das operações de limpeza, das prisões, das punições - quanto com a alegada tradição democrática brasileira"46.

As características de urgência e de antecedência do golpe civilmilitar de 1964 evidenciavam uma deficitária memória social brasileira, nos termos de François Ost. A ditadura repetia ideias, conflitos, atores, outras tentativas de golpes e exercício do autoritarismo por meio da aparência de legalidade, fórmulas que já haviam sido vivenciadas nas décadas anteriores. A falta de uma identidade de memória bem definida e socialmente protegia pode ter influenciado na repetição dessas formas de desconstituição, que abriram espaço para a instauração de um golpe de Estado e implantação da ditadura brasileira.

O segundo tempo social diz respeito ao transcurso do governo ditatorial ${ }^{47}$. Esse tempo é marcado por uma longa e diferida

ruptura'”, Em: Quaderni Fiorentini per la Storia del Pensiero Giuridico Moderno, v. 45, 2016, pp. 178: "A preocupação inicial dos dirigentes do golpe de 1964 com a edição de um ato legitimador evidencia o quão urgente era o problema jurídico-constitucional". Semelhante: Vera Karam de Chueiri; Heloísa Fernandes Câmara, "(Des)ordem constitucional: engrenagens da máquina ditatorial no Brasil pós-64". Em: Lua Nova Revista de Cultura e Política, Vol. 95, 2015, pp. 262.

44 Trecho do preâmbulo do Ato Institucional $\mathrm{n}^{\circ}$ 1: "Para demonstrar que não pretendemos radicalizar o processo revolucionário, decidimos manter a Constituição de 1946, limitando-nos a modificá-la, apenas, na parte relativa aos poderes do Presidente da República, a fim de que este possa cumprir a missão de restaurar no Brasil a ordem econômica e financeira e tomar as urgentes medidas destinadas a drenar o bolsão comunista, cuja purulência já se havia infiltrado não só na cúpula do governo como nas suas dependências administrativas". Disponivel em: http://www.planalto.gov.br/ccivil_03/ait/ait-01-64.htm.

45 Observar as seguintes expressões contidas no preâmbulo do Ato Institucional $\mathrm{n}^{\circ}$ 1: "não pretendemos radicalizar o processo revolucionário" e "decidimos manter a Constituição de 1946, limitando-nos a modificá-la".

46 Carlos Fico, "Ditadura militar brasileira: aproximações teóricas e historiográficas", Em: Revista Tempo e Argumento, Florianópolis, v. 9, n. 20, 2017, pp. 58.

47 Conferir: Vera Karam de Chueiri; Heloísa Fernandes Câmara, "(Des)ordem constitucional: engrenagens da máquina ditatorial no Brasil pós-64”, op. cit., pp. 266. As autoras subdividem três momentos no governo ditatorial: uma fase de legalidade 
continuidade. Em contrassenso à urgência que havia se operado no momento do golpe, o governo ditatorial tratou de buscar formas para prolongar sua duração no poder e adiar o retorno à democracia. Tais características são notadas no Ato Institucional no 2 (1965), no qual está escrito que a chamada revolução não apenas havia ocorrido, mas continuaria a haver, nas forças armadas e na opinião pública ${ }^{48}$.

Essa particularidade viria a se repetir nas normas de exceção editadas posteriormente. Nos preâmbulos dos seguintes Atos Institucionais $n^{\circ} 3$ e $n^{\circ} 4$ (1966), foram repetidas derivações da palavra "continuidade" para registrar que o governo seguia com os poderes revolucionários $^{49}$. O Ato Institucional $n^{\circ} 5$ (1968) resgatou trechos dos atos anteriores, em uma cadeia narrativa que parecia apresentar justificativas para a permanência do trabalho revolucionário ${ }^{50}$. Nesse ato, preferiu-se utilizar a palavra "consolidação" do ato revolucionário, que deveria ser protegido, a qualquer custo, daqueles que pretendiam destrui-1o ${ }^{51}$.

Os sinais temporais constaram expressamente no texto das normas de exceção. A revolução se "investe" no exercício do Poder Constituinte (AI-1) e esse espírito "continuará a haver" na sociedade (AI2). Para "assegurar a continuidade da obra" (AI-3), o governo "continua a deter os poderes" (AI-4), o que possibilitaria a "consolidação do movimento de março de 1964" (AI-5). Os ideais de continuidade e consolidação que haviam estampado os preâmbulos dos atos

revolucionária; uma fase de reforma política para continuidade; e uma fase de maior repressão do regime.

48 Trecho do preâmbulo do Ato Institucional $\mathrm{n}^{\circ} 2$ : "No preâmbulo do Ato que iniciou a institucionalização, do movimento de 31 de março de 1964 foi dito que o que houve e continuará a haver, não só no espírito e no comportamento das classes armadas, mas também na opinião pública nacional, é uma autêntica revolução". Disponivel em: http://www.planalto.gov.br/ccivil_03/ait/ait-02-65.htm. OLIVEIRA, Marcelo Cattoni de; PATRUS, Rafael Dilly. "Constituição e poder constituinte no Brasil pós-1964: o processo de constitucionalização brasileiro entre 'transição e ruptura'”, op. cit., pp. 179.

49 Trecho do preâmbulo do Ato Institucional $\mathrm{n}^{\circ}$ 3: "Considerando que o Poder Constituinte da Revolução lhe é intrinseco, não apenas para institucionalizá-la, mas para assegurar a continuidade da obra a que se propôs, conforme expresso no Ato Institucional $\mathrm{n}^{\circ}$ 2". Disponivel em: http://www.planalto.gov.br/ccivil_03/AIT/ait-0366.htm. Trecho do preâmbulo Ato Institucional $\mathrm{n}^{\circ}$ 4: "Considerando que o Governo continua a deter os poderes que lhe foram conferidos pela Revolução". Disponivel em: http://www.planalto.gov.br/ccivil_03/ait/ait-04-66.htm.

50 Cristiano Paixão, "Past and future of authoritarian regimes: constitution, transition to democracy and amnesty in Brazil and Chile". Em: Giornale di Storia Costituzionale, n. 30, $2^{\circ}$ semestre, 2015, pp. 92.

51 Trecho do preâmbulo do Ato Institucional $n^{\circ}$ 5: "Considerando que todos esses fatos perturbadores da ordem são contrários aos ideais e à consolidação do Movimento de março de 1964, obrigando os que por ele se responsabilizaram e juraram defendêlo, a adotarem as providências necessárias, que evitem sua destruição". Disponível em: http://www.planalto.gov.br/ccivil_03/ait/ait-05-68.htm. 
institucionais entre 1965 e 1968 triunfaram em uma ditadura que se estendeu por mais de vinte e um anos ${ }^{52}$.

Nessa aptidão de alongar o tempo, o governo teve êxito em postergar as sucessivas demandas sociais por democracia ${ }^{53}$. As tentativas fracassadas de mudanças politicas ao longo da ditadura caracterizam esse tempo em constante dilação. Desde os primeiros anos do governo ditatorial (1964-1969), havia uma promessa de retorno à democracia ${ }^{54}$. Após uma década (1974-1979), as crises institucionais e as divergências no próprio governo deram início a um discurso pela abertura da ordem politica ${ }^{55}$. Essa mudança foi definida pelo próprio governo militar como um processo lento, gradual e seguro, uma distensão controlada e composta por etapas que não podiam ser aceleradas, sob ameaça do uso de medidas excepcionais. Assim, o governo conseguiu prolongar a transferência do poder e impôs uma crença de que esse processo gradativo seria mais interessante $e$ construtivo para o país, conforme relata Bernardo Kucinski:

"Pouco antes das eleições, em agosto, o general Geisel, como se já adivinhasse a derrota, usou pela primeira vez a palavra 'distensão' para definir um processo controlado de mudanças na ordem política. Discursando aos dirigentes da Arena, em tom ao mesmo tempo ameaçador e falsamente paternalista, Geisel criticava a contundência da campanha eleitoral da oposição que conseguira desmascarar o

52 "Mais da metade dos últimos quarenta anos do século XX foram passados sob um regime militar (1964-1985). Como ainda houve um governo de transição negociada, presidido por José Sarney, até 1989, o pleno encontro do país com a democracia só veio a ocorrer na última década do milênio, a partir da eleição direta para a presidência da República naquele ano, a primeira desde 1960". Marcelo Ridenti. "Cultura". Em: Daniel Aarão Reis (Org.), Modernização, ditadura e democracia1964-2010, Vol. 5, Objetiva, Rio de Janeiro, 2014, pp. 241. Semelhante: "Lembremos que, para alguns autores, como Adriano Codato (2005), o processo de transição teria durado até 1989, incluindo, portanto, o governo do presidente civil José Sarney. Desse modo, é no mínimo razoável compreender que não houve possibilidade de participação efetivamente democrática, mas sim uma participação contida e circunscrita". Vera Karam de Chueiri; Heloísa Fernandes Câmara, "(Des)ordem constitucional: engrenagens da máquina ditatorial no Brasil pós-64”, op. cit., pp. 275.

53 Leonardo Avritzer, A moralidade da democracia: ensaios em teoria habermasiana $e$ teoria democrática, Perspectiva, São Paulo, 2012, pp. 127, 128 e 131.

54 "Tentativas de liberalizar o regime ocorreram desde o seu início. Castello assumiu a Presidência comprometendo-se com o retorno à democracia em dois anos; a linhadura o obrigaria a adiar continuamente a promessa, ao final descumprida. Desde a sua posse, Costa e Silva anunciava a alvorada da democracia, mas presidira o mergulho do país na ditadura escancarada pelo AI-5". Antônio Sérgio Rocha, "Genealogia da Constituinte: do autoritarismo à democratização". Em: Lua Nova Revista de Cultura e Política, Vol. 88, 2013, pp. 35 e 36.

55 “Geisel foi o escolhido e, portanto, seu projeto de distensão não foi resultado de seu perfil psicológico, como sugere a obra de Gaspari, mas decorreu do acúmulo histórico dessas experiências". Carlos Fico, "Ditadura militar brasileira: aproximações teóricas e historiográficas", op. cit., pp. 65. Ver também: Edison Ricardo Emiliano Bertoncelo, "Eu quero votar para presidente', uma análise sobre a Campanha das Diretas”. Em: Lua Nova Revista de Cultura e Politica, Vol. 76, 2009, pp. 172. 
regime e exigia a abertura política. Disse o general: 'Erram - e erram gravemente, porém - os que pensam poder apressar esse processo pelo jogo das pressões manipuladas sobre a opinião pública e, através desta, contra o Governo. Tais pressões servirão apenas para provocar contrapressões de igual ou maior intensidade, invertendo-se o processo de lenta gradativa e segura distensão...'. Essa era a nova receita do regime para sua própria crise. A palavra distensão supunha um processo político eventualmente mais rico e importante, mesmo dentro dos limites almejados pelo governo, do que uma 'institucionalização'. Distender podia ser até mesmo o oposto de institucionalizar. Os cuidados para que a distensão fosse 'lenta, gradativa e segura' exprimiam o caráter 'controlado' que Geisel atribuía ao processo que propunha. [...] O governo, diz ele, 'não abrirá mão dos poderes excepcionais de que dispõe, nem admite, sob quaisquer disfarces, pressões de facções ou grupos de interesse visando artificialmente queimar etapas no processo de desenvolvimento politico que se requer, ao contrário, lento, meditado e progressivo para que seja seguro, realmente duradouro, construtivo e socialmente justo" 56 .

Nos anos seguintes (1975-1985), as pautas infrutiferas de dois movimentos sociais revelariam o caráter do tempo ainda protraído: a Campanha pela Anistia e a Campanha das Diretas Já. Com grande adesão popular, o Movimento Feminino pela Anistia representava a pressão da sociedade para proteger cidadãos atingidos por atos de exceção ${ }^{57}$. Todavia, o projeto final da Lei de Anistia foi desconfigurado por dispositivos inseridos pelo governo. Em apertada votação, que contou com uma margem de apenas sete votos, aprovou-se a Lei $6.683 / 79$, com um texto que anistiava crimes cometidos por agentes da ditadura e, assim, afastava-se do objetivo original da campanha58. O Movimento Diretas Já também contava com amplo apoio da sociedade. A Proposta de Emenda Constitucional $n^{\circ} 5 / 1983$, apresentada por Dante

56 Bernardo Kucinski, Abertura, a história de uma crise, Brasil Debates, São Paulo, 1982, pp. 42 e 47.

57 Esse debate ganhou força a partir de 1975. Porém, desde 1964, já havia demandas por anistia: "Como destaca Leonardo Barbosa em sua tese de doutorado, demandas por anistia durante o período da Ditadura no Brasil tiveram início no mesmo ano do golpe, quando as primeiras vozes da oposição passaram a denunciar o paradoxo do regime, que depôs um presidente eleito e o substituiu por um general, em nome da democracia". Tradução livre do seguinte original em inglês: "As noticed by Leonardo Barbosa in his PhD Dissertation, the claim for amnesty during the Brazilian dictatorship started in the same year of the coup d'état, when the first opposing voices to the regime began to point out the constitutive paradox of the regime, which deposed an elected President and replaced him with a general in the name of democracy". Cristiano Paixão, "Past and future of authoritarian regimes: constitution, transition to democracy and amnesty in Brazil and Chile", op. cit., pp. 92.

58 "O passado ressurge como um fantasma que por si só, mesmo sem que existissem outros fatores, impede, bloqueia o processo de mudança. Não é possível obter uma abertura politica colocando os militares no banco dos réus, alegam os setores mais moderados da oposição. Nunca se garantirá efetivamente a abertura, se os crimes do passado não forem julgados, alegam a maioria dos ativistas da campanha da anistia”. Bernardo Kucinski, Abertura, a história de uma crise, op. cit., pp. 112. 
de Oliveira, registrava um indice de $84 \%$ de aprovação popular 59 . Contudo, Figueiredo enviaria uma emenda para o Congresso Nacional, por meio da qual se comprometia em restabelecer as eleições diretas no ano de 1988. Como consequência, a Emenda Dante de Oliveira foi rejeitada e, mais uma vez, a democracia se distanciava da realidade social $^{60}$. A eleição indireta de Tancredo Neves, que viria a falecer antes de tomar posse, repetia esse cenário e uma nova aproximação da sociedade com o ideal democrático seria postergada para o momento da constituinte:

"Diferentemente da Argentina (para mencionarmos um exemplo próximo), o traço marcante da memória sobre a ditadura militar brasileira não é o trauma pela violência, mas a frustração das esperanças. Naturalmente, trauma e frustração não são a mesma coisa, mas integram o vocabulário psicanalitico que predomina no debate que estamos mencionando. Talvez seja possivel identificar dois momentos culminantes que nos permitiriam entender a ditadura brasileira como um fenômeno que 'não terminou', ambos marcados pela frustração: refiro-me à Lei de Anistia, de 1979, e à Campanha das Diretas, em 1984. Não se deve confundir a Campanha da Anistia com a lei de 1979. A campanha surgiu ainda em 1975, quando foi criado o 'Movimento Feminino pela Anistia'. [...] A exclusão da anistia dos 'condenados pela prática de crimes de terrorismo, assalto, sequestro e atentado pessoal' e o chamado 'perdão aos torturadores' frustraram a expectativa otimista da campanha. A lei de 1979, que beneficiou oposicionistas, mas também foi uma autoanistia, tornou-se a principal cláusula da transição democrática dos anos 1980 e consagrou a impunidade. [...] A Campanha das Diretas foi tão impactante que muitas pessoas acreditaram na vitória. No dia da votação, quando a derrota foi confirmada, a TV mostrou pessoas chorando pelo Brasil afora. Como planejado, a escolha do presidente foi indireta, através de negociação politica que consagrou a conciliabilidade. A morte inesperada de Tancredo Neves enfatizaria o caráter frustrante do processo"61.

Nesse tempo longo e diferido, o regime militar foi capaz de controlar e distorcer o elemento do perdão, na concepção trazida por François Ost. O perdão não se confunde com esquecimento, amnésia ou com a manutenção de atores sociais nos processos de mudanças de regimes políticos; pelo contrário, memória pressupõe anamnese, lembrança, porém com ruptura e prestação de contas, inclusive quanto à violação de direitos humanos cometidos durante o regime de exceção.

59 Edison Ricardo Emiliano Bertoncelo, “Eu quero votar para presidente': uma análise sobre a Campanha das Diretas”, op. cit., pp. 186.

60 Por outro lado, "o apoio maciço da população à campanha das diretas acelerou o processo de deslegitimação do regime, questionando o principal mecanismo de sua reprodução, o Colégio Eleitoral (Lamounier, 1985)". Edison Ricardo Emiliano Bertoncelo, "Eu quero votar para presidente': uma análise sobre a Campanha das Diretas”, op. cit., pp. 189.

61 Carlos Fico, "História do Tempo Presente, eventos traumáticos e documentos sensiveis: o caso brasileiro", Varia Historia, Vol. 28, n 47, jan/jun 2012, pp. 50 a 52. 
A terceira temporalidade social localiza-se no período do processo constituinte brasileiro. Um tempo de difícil definição, em razão de particularidades contraditórias. No período constituinte, identificam-se características de aceleração e de atraso, de modernidade e de retrocesso. Por um lado, o momento da renovação constitucional representava uma esperança de transformação, com viés de modernismo e participação social-democrática. Por outro, não havia cisão com o regime anterior e o quadro constituinte estava integrado também por parlamentares ligados ao regime de exceção, o que mostrava uma interferência do governo autoritário nas disputas pela elaboração do texto constitucional62. Esses contrassensos são desenvolvidos nos três seguintes textos:

"[José Carlos Moreira Alves, então presidente do Supremo Tribunal Federal, sentado na cadeira central da mesa de direção dos trabalhos da Câmara dos Deputados, declarou abertos os trabalhos da ANC com as seguintes palavras]: Ao instalar-se esta Assembleia Nacional Constituinte, chega-se ao termo final do período de transição com que, sem ruptura constitucional e por via de conciliação, se encerra o ciclo revolucionário"63. "Conforme as teorias acadêmicas do Direito, uma Constituinte será mais legitima na medida em que resulte de uma ruptura de um processo institucional anterior, empossando-se com plena liberdade para reorganizar todos os fundamentos legais que governam o país. Os constituintes não têm, em tese, nenhum compromisso com o passado, com a legislação existente até sua posse e com os modelos de organização do Estado que vigoraram anteriormente. Em uma definição fácil, a Constituinte-modelo é aquela que se estabelece como consequência de uma revolução. Os estudiosos estabelecem uma diferença significativa entre "poder originário" da Constituinte, de padrão, digamos, ideal, e "poder reformador", daquela que se organiza sem ruptura. Segundo esse entendimento, a Constituinte de 1987-88 estava comprometida como exemplo de pureza bem antes que os eleitos começassem a debater o caráter de exclusividade da Assembleia e a situação dos senadores de 1982 - por muitas razões. A primeira, óbvia, é o fato de que foi proposta por um governo eleito conforme os ritos do regime anterior - via Colégio Eleitoral - e, por circunstâncias bem conhecidas, conduzido justamente por José Sarney, um político que até junho de 1984 presidia o partido de sustentação do regime militar. Outra, também evidente, reside na mensagem que propôs a convocação, a qual já definia de antemão que não seriam eleitos em 1986 os integrantes de uma Constituinte, mas

62 “Essa ênfase na 'transição democrática' deixou na sombra a característica disruptiva do processo de transformação analisado". Brasílio Sallum Jr., "Notas sobre a (re)democratização", Em: Angela Alonso; Miriam Dolhnikoff (Org.), 1964 - do golpe à democracia, Hedra, São Paulo, 2015, pp. 235.

63 Citação extraída de: Marcos Emílio Gomes, "A saga da carta da cidadania”, Em: Marcos Emílio Gomes (Org.), A Constituição de 1988, 25 anos: a construção da democracia \& liberdade de expressão: o Brasil antes, durante e depois da Constituinte, Instituto Vladimir Herzog, São Paulo, 2013, pp. 136. 
sim um Congresso regular que viveria a especial situação de escrever uma nova Carta64. "[Pronunciamento de Ulysses Guimarães em resposta à alegação divulgada por José Sarney de que os brasileiros tinham receio de que a Constituição tornasse o país ingovernável]: Esta Constituição terá cheiro de amanhã, não de mofo. A fome, a miséria, a ignorância, a doença inassistida, é que são ingovernáveis. [...] Repito: esta será a Constituição cidadã. Porque recuperará como cidadãos milhões de brasileiros"65.

O primeiro trecho se refere à fala do Ministro Moreira Alves no dia da abertura dos trabalhos da Assembleia Nacional Constituinte. Observa-se o uso das palavras "sem ruptura", "conciliação" e "ciclo revolucionário". Segundo Moreira Alves, a revolução era um ciclo que se completava e não um governo ilegítimo que havia decaído. Em outras palavras, tratava-se de um tempo que se consumava, não de uma ruptura entre ditadura e democracia. A segunda transcrição mostra como os trabalhos constituintes estavam presos a uma composição politica pretérita, um passado que parecia não passar. O terceiro fragmento apresenta o otimismo de Ulisses Guimarães ao realçar a cidadania e identificar a Constituição Federal com o amanhã, um tempo dirigido a um novo futuro66.

O período constituinte apresenta contrastes de celeridade e retração. De um lado, o tempo mostrava-se acelerado, em virtude da intensidade dos trabalhos da Assembleia Nacional Constituinte. Foram consumidos vinte meses de trabalhos, negociações e debates, sessões dia e noite, sobre os diversos temas de natureza constitucional e que ocupavam a atenção central do país naquele momento histórico ${ }^{67}$. De outro, o tempo apresentava-se tardio, em razão do transcurso de duas décadas sem democracia, bem como pelas demandas frustradas de outros momentos potencialmente constituintes ${ }^{68}$. Havia ainda uma nova questão que atrasava e ameaçava a democracia: a exigência de José Sarney quanto à manutenção do mandato de cinco anos ${ }^{69}$. Mesmo

64 Marcos Emílio Gomes, “A saga da carta da cidadania”, op. cit., pp. 144 e 145.

65 Antônio Sérgio Rocha, "Genealogia da Constituinte: do autoritarismo à democratização", op. cit., pp. 84.

66 Curiosamente, a retórica de um novo futuro também havia sido utilizada no preâmbulo do Ato Institucional $\mathrm{n}^{\circ}$ 1: "É indispensável fixar o conceito do movimento civil e militar que acaba de abrir ao Brasil uma nova perspectiva sobre o seu futuro".

67 Antônio Sérgio Rocha, "Genealogia da Constituinte: do autoritarismo à democratização", op. cit., pp. 84.

68 As pautas das greves do ABC paulista do final da década de 70 pediam a elaboração de uma constituinte. Eduardo G. Noronha. "Ciclo de greves, transição politica e estabilização: Brasil, 1978-2007”. Em: Lua Nova Revista de Cultura e Politica, Vol. 76, 2009, pp. 120. Após as eleições de Tancredo, no discurso de lançamento da Nova República, Ulisses previa um Poder Constituinte, que deveria ter sido eleito em 1986 para a elaboração de uma nova carta constitucional. Antônio Sérgio Rocha. "Genealogia da Constituinte: do autoritarismo à democratização", op. cit., pp. 53.

69 “Sem ingenuidade, é preciso observar que essa era uma força poderosa, liderada pelo comandante supremo das Forças Armadas, o presidente. Mas, até pelo tamanho 
com contradições e imperfeições, situada em um campo indefinido entre o novo e o velho, a Assembleia Nacional Constituinte representava uma conquista popular, originada de importantes lutas políticas e movimentos sociais brasileiros:

"A instalação de uma nova Constituinte, em 1987, não foi uma medida politica "ofertada" à sociedade brasileira por alguns parlamentares comprometidos com a redemocratização - como o discurso governamental do período sustentava. Ela foi uma resposta a um amplo movimento social que congregou experiências e iniciativas por todo o Brasil, mobilizando entidades civis, grupos sociais e pessoas as mais diversas"70.

"A ANC foi bitolada pela dialética venenosa e destrutiva da "transição". Mas se contrapôs a ela e a superou, embora os frutos da vitória não sejam aqueles a que os democratas liberais, radicais, nacionalistas, socialistas ou comunistas aspiravam. A esquerda, em particular, em suas várias correntes, cedeu à urgência das reformas sociais, da revolução democrática e da revolução nacional, postergando para outros tempos a luta pela conquista do poder. Portanto, ninguém sai satisfeito. Mas todos reconhecem que o 'possivel democrático' poderá ser atingido e impor-se como um novo ponto de partida, na criação de uma verdadeira República, expurgada de tiranos civis e militares, bem como de suas práticas seculares de violência e de monopólio do poder estatal"71.

"Para uma teoria vocacionada à reelaboração da democracia deliberativa e, a partir disso, à problematização do conceito de representação política, o momento constituinte em 1987/1988 consiste em um fenômeno discursivo que ganha legitimidade no tempo, como um acontecimento sem início nem fim definidos, e merge do interregno das lutas políticas e sociais, vivificando-se com a edificação da identidade aberta, polissêmica e plural do sujeito constitucional brasileiro. [...] Assim, não obstante a leitura formalista e limitadora feita por parcela dos constitucionalistas brasileiros, a longa gestação do processo constituinte de 1987/1988 indica o papel de destaque que os movimentos sociais desempenharam no estabelecimento da nova ordem constitucional"72.

desse poder, fica fácil imaginar quantas crises foram evitadas ou reduzidas ao se manter aberta a interlocução com Sarney". Marcos Emílio Gomes, "A saga da carta da cidadania", op. cit., pp. 146.

70 Maria Helena Versiani, "Constituinte de 1987/1988: a sociedade brasileira vive a democracia". Em: Samantha Viz Quadrat (Org.), Não foi tempo perdido: os anos $80 \mathrm{em}$ debate, 7Letras, Rio de Janeiro, 2014, pp. 363.

71 Florestan Fernandes, A Constituição inacabada - vias históricas e significado politico, op. cit., pp. 159.

72 Marcelo Cattoni de Oliveira; Rafael Dilly Patrus, "Constituição e poder constituinte no Brasil pós-1964: o processo de constitucionalização brasileiro entre 'transição $e$ ruptura'”, op. cit., pp. 186 e 188. 
Assim, após mais de duas décadas de ditadura, o país havia finalmente editado uma nova Constituição Federal, uma carta com texto moderno, fruto de exigências populares e que apontava para novos horizontes. A Constituição enquadra-se no conceito de um pacto, ou seja, nos termos de François Ost, surge como um elemento de promessa. Um compromisso de ordem jurídico-democrática, pautado pela pluralidade e pelo respeito aos direitos fundamentais.

A materialização dessa promessa foi dificultada pela presença de antigos atores no processo constituinte. Contudo, mesmo com tais dificuldades, o país se uniu para alterar o modelo político nesse pacto constitucional. O período que se segue à promulgação da Constituição de 1988 insere-se na quarta temporalidade apontada neste trabalho.

O quarto tempo social representa o período de uma nova democracia fundamentada em base constitucional. No momento em que este artigo é redigido, a Constituição Federal completa mais de trinta anos de vigência. Ao longo desse período, o texto original foi modificado por cento e uma emendas constitucionais. Inúmeros atos infraconstitucionais regulamentaram e imprimiram novos sentidos às disposições da Constituição Federal. Algumas dessas alterações permitiram que a Constituição Federal acompanhasse a evolução do seu tempo ${ }^{73}$. Outras representam retrocessos de direitos conquistados ao longo de décadas de lutas sociais ${ }^{74}$.

Isso significa que a imutabilidade normativa pode ser tão corrosiva quanto eventual mudança que prejudique uma regra social mínima, especialmente protegida pelo constituinte ${ }^{75}$. $\mathrm{O}$ momento atual é, portanto, propício para sopesar avanços e regressos constitucionais. Uma oportunidade para requestionamentos, na concepção de François Ost. Neste trabalho, o período pós-constituinte será analisado com recorte nas medidas adotadas no campo da Justiça Transicional. Aqui,

73 "O protesto à esquerda e à direita pode ser visto como um atestado de atendimento à maioria, e as emendas posteriores à promulgação, mesmo as que ainda venham a ser feitas só mostram mais uma virtude da Constituição: a de que ela não está parada no tempo como uma trava ao progresso". Marcos Emílio Gomes, "A saga da carta da cidadania", op. cit., pp. 179.

74 Alguns exemplos: a) Emenda Constitucional 95, que limita as despesas públicas por vinte anos (disponivel em: http://www.planalto.gov.br/ccivil_03/constituicao/emendas/emc/emc95.htm); b) Lei 13.467, que alterou mais de cem artigos da Consolidação das Leis Trabalhistas (disponivel em: http://www.planalto.gov.br/ccivil_03/_ato20152018/2017/lei/113467.htm); c) a Lei 13.941/2017, que transfere para a competência da Justiça Militar da União o julgamento de crimes dolosos contra a vida praticados por agentes das forças armadas contra civis (disponivel em: http://www.planalto.gov.br/ccivil_03/_ato2015-2018/2017/lei/113491.htm); e d) Portaria do Ministério do Trabalho 1.129/2017, que flexibiliza o conceito de trabalho análogo à escravidão (disponivel em: https://www.in.gov.br/materia//asset_publisher/Kujrw0TZC2Mb/content/id/19356195/do1-2017-10-16-portaria-n1-129-de-13-de-outubro-de-2017-19356171).

75 François Ost, O tempo do direito, op. cit., pp. 316. 
optou-se por denominar essa temporalidade social de Tempo da Justiça de Transição.

\section{O TEMPO SOCIAL DA JUSTIÇA DE TRANSIÇÃO NO BRASIL}

O tempo do golpe apresentou-se antecedente e urgente, marcado por uma deficiência de memória. O tempo da ditadura, longo e prorrogado, evidenciou a distorção do conceito de perdão. O tempo da constituinte, simultaneamente moderno e obsoleto, resultou em uma promessa constitucional. O tempo da Justiça de Transição pode ser assinalado por duas características: tardio e incompleto, o que deve conduzir a requestionamentos pela sociedade brasileira.

Os dispositivos previstos na Constituição Federal relacionados à Justiça de Transição, artigos $8^{\circ}$ e $9^{\circ}$ do Ato das Disposições Constitucionais Transitórias, retroagem a fatos ocorridos desde 1946, o que, atualmente, representa um período de mais de sete décadas de conflitos e impasses intergeracionais. Após a promulgação da Constituição Federal de 1988, foram necessários sete anos até a edição da primeira norma federal sobre Justiça de Transição, a chamada Lei de Mortos e Desaparecidos (1995) ${ }^{76}$. Mais sete anos se passaram até que fosse regulamentado o artigo $8^{\circ}$ do Ato das Disposições Constitucionais Transitórias quanto às reparações indenizatórias e direitos correlatos das vítimas da ditadura (2002) $)^{77}$. Nove anos adicionais transcorreram até a criação de uma Comissão Nacional da Verdade no país $(2011)^{78}$.

Em outras palavras, o período entre a promulgação da Constituição Federal e a edição da lei de regulamentação do artigo $8^{\circ}$ do ADCT (1988-2002) é praticamente o mesmo prazo transcorrido entre o golpe e a edição da lei de anistia do governo militar (1964-1979). Da mesma forma, o transcurso entre a Constituição Federal e a criação da Comissão Nacional da Verdade (1988-2011) é equivalente à duração da própria ditadura (1964-1988). Além do atraso, esses números indicam que a implantação de politicas de justiça de transição foi igualmente lenta e gradual, tal como o próprio modelo de transição política imposto pelo regime de exceção.

Há uma relação direta entre os tempos sociais. A urgência dos atos que haviam golpeado a democracia, a constante dilação do retorno ao cenário democrático e a ausência de ruptura no processo constituinte

76 Brasil, Lei $\mathrm{n}^{\circ}$ 9.140, de 1995. Disponivel em: https:/ / www2.camara.leg.br/legin/fed/lei/ 1995/lei-9140-4-dezembro-1995-348760normaatualizada-pl.html. Nesse sentido: Carlos Fico, "História do Tempo Presente, eventos traumáticos e documentos sensiveis: o caso brasileiro”, op. cit., pp. 53.

77 Brasil, Lei $n^{\circ} 10.559$, de 2002, decorrente da conversão da Medida Provisória ${ }^{\circ}$ 65, de 2001. Disponivel em: http: / /www.planalto.gov.br/ccivil_03/leis/2002/110559.htm.

78 Brasil, Lei $\mathrm{n}^{\mathrm{o}}$ 12.528, de 2011. Disponivel em: http://www.planalto.gov.br/ccivil_03/_ato2011-2014/2011/lei/112528.htm. 
mostram que o governo autoritário exercia um domínio do tempo, uma força capaz de minar os anseios populares e de exaurir a busca por uma justiça social. Após anos de enfrentamento até a conquista das eleições diretas e de uma nova carta republicana, temas referentes à Justiça de Transição não pautavam as prioridades brasileiras nos primeiros momentos da etapa pós-constituinte.

Essa demora em implementar uma agenda de Justiça de Transição, após a redemocratização política, não representa uma exclusividade brasileira ${ }^{79}$. Mas o perfil de morosidade da Justiça de Transição também pode ser explicado pela permanência de estruturas conservadoras e poderes dominantes, mantidos em cena após a redemocratização:

"Para além de todas as especificidades, para além mesmo da divisão em dois grandes blocos, é marca característica da redemocratização a presença, sob diferentes figuras, de uma mesma cultura política conservadora, estruturada para bloquear transformações de grande envergadura, para manter a redemocratização em tempo lento. [...] A história brasileira do século XX é marcada amplamente por governos autoritários e/ou coronelismo, vale dizer, por regimes repressivos que bloqueiam a organização coletiva e a luta por direitos. O conservadorismo pemedebista se dá, ao contrário, em ambiente democrático, de maneira que não lhe é possivvel bloquear na marra a implementação de direitos. O único caminho que lhe resta é controlar a velocidade de sua implementação efetiva, praticada segundo critérios altamente seletivos"80.

"Não é casual, assim, que o Golpe e a Ditadura sejam mobilizados em nossos 'dramas sociais' no início da segunda década do século XXI; também não é por acaso que nossa Comissão da Verdade só tenha se

79 “A concepção de que a justiça transicional ocorre exclusivamente durante uma limitada janela de oportunidade, surgida com a mudança para um regime democrático, ignora o fato de que os processos de responsabilização, busca da verdade, programas de reparação e outras medidas consideradas instrumentos da justiça transicional são recorrentemente empregadas muito tempo depois da instalação de um governo eleito democraticamente. $\mathrm{Na}$ realidade, os processos judiciais envolvendo graves violações de direitos humanos cometidas sob regimes de repressão são frequentemente assumidos, reassumidos ou revisados, muitos anos após um governo democrático ter se instalado". Tradução livre deste original em lingua inglesa: "Assuming that transitional justice exclusively occurs in the limited window of opportunity created by a democratic regime change further ignores the fact that accountability processes, truth-seeking, reparation programs and other measures usually considered tools of transitional justice are often utilized long after a democratically elected government has been installed. In reality, justice processes relating to serious human rights abuses committed under repressive regimes are frequently assumed, reassumed or revised, many years after democratic rule has been installed". Thomas Obel Hansen, "The Time and Space of Transitional Justice", Em: Transitional Justice Institute Research Paper, $\mathrm{n}^{\circ}$ 16-11, Edward Elgar Publishin, Reino Unido, 2016, pp. 2.

80 Marcos Nobre, "Conservadorismo em chave democrática", Em: Angela Alonso; Miriam Dolhnikoff (Org.). 1964 - do golpe à democracia. Hedra, São Paulo, 2015, pp. 249 e 256. Semelhante: Florestan Fernandes, A Constituição inacabada - vias históricas e significado politico, op. cit., pp. 51 . 
constituído, sem poder punitivo, depois de quase trinta anos do fim da Ditadura. Nessa direção, Abreu afirma que 'no contexto crítico dos anos 1960, figurava-se a história política da década de 1930 como resposta adequada aos dramas do presente. Um drama desdobrava-se em outro, requerendo interpretações que ultrapassassem os limites da memória histórica' (2012, pp.25). As disputas em torno da questão da desigualdade, que transforma cerca de $30 \%$ da população em excluídos sociais é, assim, a base dos atuais conflitos sociais no Brasil (Souza, 2014). As recentes (e frágeis) conquistas das classes populares em termos de educação e saúde estão, certamente, no centro do debate, ainda que intimamente atreladas a 'blindagens' e 'pactos' que 'fundaram' e permaneceram durante a 'nova república' (Pochmann, 2015; Nobre, 2013)"81.

Também é possivel afirmar que o quarto tempo social se apresenta inacabado, pois as principais questões que dizem respeito à Justiça de Transição permanecem em constante discussão no panorama brasileiro atual. Ainda se discute a responsabilidade dos agentes que violaram direitos humanos na ditadura, questão que representa um impasse entre a Corte Constitucional do país e a Corte Interamericana de Direitos Humanos ${ }^{82}$. Uma abertura ampla dos dados e documentos da ditadura ainda não foi realizada. Os nomes dos logradouros públicos estão em constantes disputas permeadas por uma polarização de opiniões sobre o período da ditadura. Tampouco foram efetivadas reformas institucionais capazes de estabilizar a crença dos cidadãos nas estruturas democráticas ${ }^{83}$. Permanece pendente a apreciação de aproximadamente dez mil requerimentos de vítimas, cujo julgamento encontra-se prejudicado pelo esvaziamento das condições de trabalho e

81 Mateus Henrique de Faria Pereira. "Nova direita? Guerras de memória em tempos de Comissão da Verdade (2012-2014)", Varia Historia, Vol. 31, n 57, set/dez 2015, pp. 887. Semelhante: Vladimir Safatle, Só mais um esforço, Três Estrelas, São Paulo, 2017, pp. 43 e 44. Na mesma linha: Henry Rousso, A última catástrofe: a história, o presente, o contemporâneo, Trad. Fernando Coelho e Francisco Coelho, FGV, Rio de Janeiro, 2016, pp. 220.

82 No Supremo Tribunal Federal: ADPF 153 e ADPF 320. Na Corte Interamericana: Caso Gomes Lund vs. Brasil e Caso Herzog vs. Brasil. Em sentido semelhante, quanto ao caso espanhol: "Portanto, embora houvesse um clima político mais receptivo do que existe atualmente na Espanha, propostas como a feita em 2014 pelo Relator Especial das Nações Unidas, Pablo de Greiff, a fim de que o Estado derrogasse a Lei de Anistia para permitir o julgamento de crimes do franquismo, infelizmente, esbarram na realidade". Tradução livre do seguinte original em língua espanhola: "Por ello, aunque hubiera un clima politico más receptivo del que hay actualmente en España, propuestas como la efectuada en 2014 por el relator especial de Naciones Unidas, Pablo de Greiff, de que el Estado derogue la Ley de Amnistía para permitir el juzgamiento de los crimenes del franquismo, están lamentablemente condenadas a estrellarse con la realidad". Josep Tamarit Sumalla, "Memoria histórica y justicia transicional en España: el tiempo como actor de la justicia penal", Em: Anuario Iberoamericano de Derecho Internacional Penal, ANIDIP, vol. 2, 2014, pp. 64.

83 Relatórios recentes mostram baixos índices de confiança dos cidadãos nas instituições democráticas. Ver: https://direitosp.fgv.br/sites/direitosp.fgv.br/files/arquivos/relatorio_icj_1sem2017.p df, pp. 13. Acesso em: 13/01/2020. 
pela composição da atual Comissão de Anistia, bem como pelo encerramento dos trabalhos das Clínicas do Testemunho ${ }^{84}$.

Parte da sociedade brasileira ainda não foi capaz de compreender que a prestação de contas, em qualquer extensão, daqueles que violaram direitos humanos em regimes autoritários não consiste em revanchismo; mas sim em medida de justiça, que reflete um conteúdo de perdão, na concepção de François Ost ${ }^{85}$. Se a construção de qualquer memória social pressupõe uma seletividade entre lembranças e esquecimentos, importa que, nesse caminho, não sejam olvidadas as greves, as lutas e os movimentos sociais, que norteavam a busca de uma democracia constitucional e de uma sociedade mais justa em tempos de exceção. Tampouco se pode deixar de oferecer o devido reconhecimento àqueles indivíduos singulares, que dedicaram desde a dignidade até a própria existência para alcançar um objetivo democrático ${ }^{86}$.

Essas incompletudes deixam espaço aberto para que as atuais autoridades do Poder Executivo brasileiro possam minimizar a catastrófica experiência ditatorial brasileira e exaltar outras ditaduras latino-americanas. Não é demasiado, portanto, repetir que o Brasil se encontra diante de um momento de requestionamento, uma oportunidade para revisitar a agenda de Justiça de Transição que ainda se encontra incompleta, mais de trinta anos após a promulgação da Constituição Federal. Enfrentar com equilíbrio e serenidade os tempos sociais da experiência ditatorial significa fortalecer uma democracia nova, mas frequentemente ameaçada em sua modernidade.

\section{CONSIDERAÇÕES FINAIS}

As características temporais aqui expostas conduzem à conclusão de que o tempo não pode se apresentar como obstáculo para a efetivação do processo transicional brasileiro. A agenda da Justiça de Transição não mais pode sofrer com atrasos, com incompletudes e, mais recentemente, com retrocessos no ciclo democrático, sob pena de se agravarem fissuras não reparadas no Estado Democrático de Direito.

O desafio do jurista, portanto, é criar "um tempo jurídico e social que saiba inovar e durar ao mesmo tempo"87. Esse é o tempo da Justiça de Transição. Um tempo que respeita o passado e se põe como uma via aberta para o futuro. Uma temporalidade que tenta atingir mais do que uma democracia possivel, mas uma democracia constitucional que

84 Eneá de Stutz e Almeida, "Uma breve Introdução à Justiça de Transição no Brasil", Em: Justiça de Transição no Brasil: apontamentos. Eneá de Stutz e Almeida (Org.) CRV, Curitiba, 2017, pp. 21 e 22.

85 François Ost, O tempo do direito, op. cit., pp. 148 e 175.

86 Hannah Arendt, A condição humana, Tradução de Roberto Raposo, 11 a ed., Forense Universitária, Rio de Janeiro, 2013, pp. 119.

87 François Ost, O tempo do direito, op. cit., pp. 232. 
conjuga memória, perdão, promessa e requestionamento. Um direito que se permita transformar, em busca de equidade e justiça social, mas que impeça retrocessos e repetição de erros historicamente prejudiciais ao pleno desenvolvimento da paz social e da cidadania brasileiras. É o desafio que se apresenta neste momento histórico-constitucional, a ser enfrentado pelo jurista.

\section{BIBLIOGRAFIA}

AGOSTINHO. Confissões. Livro XI. Trad. Arnaldo do Espírito Santo et al. Covilhã: Luso Sofia Press, 2008.

Anthony W. Pereira, Ditadura e repressão: o autoritarismo e o estado de direito no Brasil, no Chile e na Argentina, Trad. Patricia de Queiroz Carvalho Zimbres, Terra e Paz, São Paulo, 2010.

Antônio Sérgio Rocha, "Genealogia da Constituinte: do autoritarismo à democratização”, Em: Lua Nova Revista de Cultura e Política, Vol. 88, 2013.

Aristóteles, Física I e II, Trad. Lucas Angioni, Unicamp, Campinas, 2009.

Auro Moura Andrade, Um Congresso contra o arbitrio: diários $e$ memórias, Nova Fronteira, Rio de Janeiro, 1985.

Bernardo Kucinski, Abertura, a história de uma crise, Brasil Debates, São Paulo, 1982.

Brasil, Lei $\mathrm{n}^{\circ}$ 10.559, de 2002, decorrente da conversão da Medida Provisória $n^{\circ}$ 65, de 2001.

Brasil, Lei $n^{\circ} 12.528$, de 2011.

Brasil, Lei no 9.140, de 1995.

Brasílio Sallum Jr., "Notas sobre a (re)democratização", Em: Angela Alonso; Miriam Dolhnikoff (Org.), 1964 - do golpe à democracia, Hedra, São Paulo, 2015.

Carlos Fico, "Ditadura militar brasileira: aproximações teóricas e historiográficas", Em: Revista Tempo e Argumento, Florianópolis, v. 9, n. 20, 2017.

Carlos Fico, "História do Tempo Presente, eventos traumáticos e documentos sensiveis: o caso brasileiro". Varia Historia, Vol. 28, n ${ }^{\circ} 47$, jan/jun 2012.

Cornelius Castoriadis, A instituição imaginária da sociedade, $3^{\mathrm{a}}$ ed., Paz e Terra, Rio de Janeiro, 1982.

Cornelius Castoriadis, As encruzilhadas do labirinto III: o mundo fragmentado, Trad. Rosa Maria Boaventura, Paz e Terra, Rio de Janeiro, 1992. 
Cristiano Paixão, "Past and future of authoritarian regimes: constitution, transition to democracy and amnesty in Brazil and Chile", Em: Giornale di Storia Costituzionale, n. 30, $2^{\circ}$ semestre, 2015.

Cristiano Paixão, Modernidade, tempo e direito, Del Rey, Belo Horizonte, 2002.

Daniel de Mendonça, O golpe civil-militar de 1961: Critica a uma explicação hegemônica, Em: Política e Sociedade, n 14, abril de 2009.

Edison Ricardo Emiliano Bertoncelo, "Eu quero votar para presidente': uma análise sobre a Campanha das Diretas", Em: Lua Nova Revista de Cultura e Politica, Vol. 76, 2009.

Edmund Husserl, Leçons pour une phénoménologie de la conscience intime du temps, Trad. Henri Dussort, Presses Universitaires de France, Paris, 1964.

Eduardo G. Noronha, "Ciclo de greves, transição politica e estabilização: Brasil, 1978-2007’. Em: Lua Nova Revista de Cultura e Politica, Vol. 76, 2009.

Emmanuel Kant, Crítica da Razão Pura, Trad. J. Rodrigues de Merege, Acrópolis, São Paulo, 2001.

Eneá de Stutz e Almeida, "Uma breve Introdução à Justiça de Transição no Brasil", Em: Justiça de Transição no Brasil: apontamentos, Eneá de Stutz e Almeida (Org.), CRV, Curitiba, 2017.

Fernand Braudel, La historia y las ciencias sociales, Trad. Josefina Gómes Mendonza, $3^{a}$ ed., Alianza Editorial, Madrid, 1974.

Flávia Biroli, "Representações do golpe de 1964 e da ditadura na midia: sentidos e silenciamentos na atribuição de papéis à imprensa, 1984-2004", Varia Historia, Vol. 25, n 41, jan/jun 2009.

Florestan Fernandes, A Constituição inacabada - vias históricas $e$ significado politico, Estação Liberdade, São Paulo, 1989.

François Ost, O tempo do direito, Trad. Maria Fernanda Oliveira, Instituto Piaget, Lisboa, 1999.

Franz Brentano, Psychology from an Empirical Standpoint, Trad. Rancurello, A.C. et al., Londres: Routledge, 1995.

Hannah Arendt, A condição humana, Trad. de Roberto Raposo, $11^{\mathrm{a}}$ ed., Forense Universitária, Rio de Janeiro, 2013.

Hannah Arendt, Entre o passado e o futuro, Trad. Mauro W. Barbosa,Perspectiva, São Paulo, 2016.

Henri Bergson, Obras Escogidas, Trad. José Antonio Miguez, Aguilar S.A. de Ediciones, Cidade do México, 1963.

Henry Rousso, A última catástrofe: a história, o presente, o contemporâneo, Trad. Fernando Coelho e Francisco Coelho, FGV, Rio de Janeiro, 2016. 
José Reis, "Estudo sobre o Tempo", Em: Revista Filosófica de Coimbra Vol. $6 \mathrm{n}^{\circ}$ 12. Coimbra: Instituto de Estudos Filosóficos da Faculdade de Letras da Universidade de Coimbra, 1997.

José Reis, “Estudo sobre o Tempo". Em: Revista Filosófica de Coimbra Vol. $5 \mathrm{n}^{\circ}$ 9. Coimbra: Instituto de Estudos Filosóficos da Faculdade de Letras da Universidade de Coimbra, 1996.

Josep Tamarit Sumalla, "Memoria histórica y justicia transicional en España: el tiempo como actor de la justicia penal", Em: Anuario Iberoamericanode Derecho Internacional Penal, ANIDIP, vol. 2, 2014.

Leonardo Avritzer, A moralidade da democracia: ensaios em teoria habermasiana e teoria democrática, Perspectiva, São Paulo, 2012.

Lucilia Neves Delgado, “Brasil: 1954 - Prenúncios de 1964”, Varia Historia, Vol. 21, n 34, jul. 2005.

Manoel Luíz Salgado Guimarães, "O presente do passado: as artes de Clio em tempos de memória". Em: Martha de Abreu; Rachel Soihet; Rebeca Gontijo (Org.), Cultura Politica e leituras do passado: historiografia e ensino de história, Civilização Brasileira, Rio de Janeiro, 2007.

Marcelo Cattoni de Oliveira; Rafael Dilly Patrus, "Constituição e poder constituinte no Brasil pós-1964: o processo de constitucionalização brasileiro entre 'transição e ruptura'”, Em: Quaderni Fiorentini per la Storia del Pensiero Giuridico Moderno, v. 45, 2016.

Marcelo Jasmin, “Futuro(s) presente(s)", Em: Adauto Novaes (Org.), Mutações: o futuro não é mais o que era, Edições SESC, São Paulo, 2013.

Marcelo Ridenti, "Cultura", Em: Daniel Aarão Reis (Org.), Modernização, ditadura e democracia - 1964-2010, Vol. 5, Objetiva, Rio de Janeiro, 2014.

Marcos Emílio Gomes, "A saga da carta da cidadania", Em: Marcos Emílio Gomes (Org.), A Constituição de 1988, 25 anos: a construção da democracia \& liberdade de expressão: o Brasil antes, durante e depois da Constituinte, Instituto Vladimir Herzog, São Paulo, 2013.

Marcos Nobre, "Conservadorismo em chave democrática", Em: Angela Alonso; Miriam Dolhnikoff (Org.), 1964 - do golpe à democracia, Hedra, São Paulo, 2015.

Maria Helena Versiani, Constituinte de 1987/1988: a sociedade brasileira vive a democracia, Em: Samantha Viz Quadrat (Org.), Não foi tempo perdido: os anos 80 em debate, 7Letras, Rio de Janeiro, 2014.

Martin Heidegger, Ser e tempo, Trad. Fausto Castilho, Unicamp, Campinas, 2012.

Mateus Henrique de Faria Pereira, "Nova direita? Guerras de memória em tempos de Comissão da Verdade (2012-2014)", Varia Historia, Vol. 31, n 57, set/dez 2015. 
Maud Chirio, A politica nos quartéis: revoltas e protestos de oficiais na ditadura militar brasileira, Trad. André Telles, Zahar, Rio de Janeiro, 2012.

Niklas Luhmann, The differentiation of society, Trad. Stephen Holmes e Charles Larmore, Columbia University Press, Nova Iorque, 1982.

Norbert Elias, Du Temps, Trad. M. Hulin, Fayard, Paris, 1996.

Paul Ricœur, Tempo e Narrativa, Tomo III, Trad. Roberto Leal Ferreira, Papirus, Campinas, 1997.

Platão, Timeu-Critias, Trad. Rodolfo Lopes, Centro de Estudos Clássicos e Humanísticos, Coimbra, 2011.

Reinhart Koselleck, Futuro pasado: para una semántica de los tiempos históricos, Trad. Norberto Smilg, Paidós, Barcelona, 1993.

Thomas Obel Hansen, "The Time and Space of Transitional Justice", Em: Transitional Justice Institute Research Paper, $\mathrm{n}^{\circ}$ 16-11, Edward Elgar Publishin, Reino Unido, 2016.

Vera Karam de Chueiri; Heloísa Fernandes Câmara, "(Des)ordem constitucional: engrenagens da máquina ditatorial no Brasil pós-64”. Em: Lua Nova Revista de Cultura e Política, Vol. 95, 2015. 2017.

Vladimir Safatle, Só mais um esforço, Três Estrelas, São Paulo,

Enviado el (Submission Date): 18/10/2020

Aceptado el (Acceptance Date): 22/12/2020 